\title{
A lintel of Amenemhat I at the Egyptian Museum in Cairo
}

\author{
Abeer Anany \\ The Faculty of Monuments and Tourist Guidance \\ Misr University for Science and Technology
}

\begin{abstract}
The object studied in this paper is a block of limestone that attracted the researcher by some of its unusual details but found out in the course of the research that it has never been published. The aim of this paper is to publish this block and discuss these details.
\end{abstract}

Keywords: lintel, block, Egyptian museum, pyramid complex, Amenemhat I

\section{Block General Information}

The block is an upper lintel from the pyramid complex of Amenemhat I at El Lisht. It encloses a scene, the king seated on two thrones in a double pavilion, related to the sed-feast of Amenemhat I.

\section{Current Location}

This block is currently existent in the Egyptian Museum, Cairo, J. d'E. 40484. According to the museum records, it was brought to the museum in 1908 .

\section{Discovery and Original Location of the Block}

This lintel was excavated at El-Lisht as a reused block in the walls of King Amenemhat I's mortuary temple, to the east of his pyramid. The Egyptian Museum database does not specify the excavation expedition discovered this piece; but only mentions it was brought to the museum in 1908.

Two expeditions worked extensively at El-Lisht. The first is of the French Institute IFAO under Gustave Jequier and Joseph E. Gautier in 1894-95, whose work was focused more on the southern pyramid of Senusert I. ${ }^{1}$ The second expedition is of the Metropolitan Museum of Art of New York, who worked in the area from 1907 till the early twenties of the previous century, and focused more on the Northern pyramid of Amenemhat I. ${ }^{2}$ Neither expedition mentioned the block studied in this paper. However, as the museum records specify the date 1908 as its entry date; it might be presumed it was found by the Egyptian Expedition of the Metropolitan Museum of Art. ${ }^{3}$ Another piece found there has a scene related to the block studied in this paper, now in the Metopolitan Museum of Arts, MMA 08.200.5. ${ }^{4}$ It is the upper third of a lintel in which the king is represented in the rituals of the sed festival. ${ }^{5}$ These blocks were originally from the reliefs of the king's mortuary temple on the east side of his pyramid at Lisht. They display representations of ceremonies associated with the sed festival. It must be noted, though some of these reused blocks date back to the time of Amenemhat I and to his co-regency with Senusert I. ${ }^{6}$

Some Egyptologists discussed the Dating and motives for these blocks to have been dismantled and reused in the walls of the king's mortuary temple. ${ }^{7}$ They uncovered, it is hard to confirm the date when these blocks were dismantled. This might have been done by king Amenemhat I later in his reign, or during his co-regency with Senusert I either. Moreover, William Kelley Simpson, ${ }^{8}$ suggests this may have been done by a later king, who might have tried to usurp the pyramid and temple. He finds it hard to confirm the assumption that there was another set of reliefs applied during the co-regency of Amenemhat I and Senusert I. He imputed this to the existence of other blocks dating back to the coregency period, uncovered under the temple as well.

However, Hays believed the mortuary temple of Amenemhat I was originally built of mud-brick with limestone trim, and probably, was torn down in the early years of the independent rule of Senusert I, and rebuilt throughout of limestone. He draws attention to some texts of the second temple structure, where Senusert I is making offerings to his father. In some of these texts, the expression nswt Ds.f, 'the king himself, 'the actual king', precede the names of Senusert I. Hays takes this expression as an indication when these blocks were carved, Senusert I was the sole ruler of the country. ${ }^{9}$ Other Egyptologists, however, find the combining of the two kings' names and the use of nswt Ds.f, "the king himself" to indicate the co-regency between the two kings, and dated the building they came from to the coregency period, which means the last Ten years of Amenemhat I reign. ${ }^{10}$

Dorothea Arnold provided evidence that King Amenmehat I moved to Ithj-Tawy late in his reign. ${ }^{11}$ This would match the opinion of William Kelly Simpson that Amenemhat I celebrated or planned to celebrate his first sed-feast late 
in his reign. ${ }^{12}$ In any case, the block studied in this research seem to have belonged to a building probably erected during the last decade of Amenemhat I reign. Future research might investigate more on the date -and motives- this building was dismantled.

\section{Block Description}

This block is part of an upper lintel made out of fine limestone. It is rectangular in shape, and partly broken from the left side. It is carved in fine high relief with remains of the original colors that shall be described below. The block is in a good state of preservation in spite of some cracks.

Mr. Alaa El-Said Ali and Mr. Ahmed Abd El-'Aziz are two restoration specialists in the museum, they examined the block for the research. They explained most of those cracks are micro-cracks, superficial cracks related to the stone physics. They could also detect one major crack with traces of an old primitive restoration, perceived by naked eye. The block has a glass cover from the front side, and a surrounding frame nailed into the block itself and the museum floor either; so making it too risky to open, as decided by the museum committee that examined it. For the safety of the block; pictures were taken without removing the glass frame (Figs.1, 2).

\section{Date of Block}

The block dates back to the time of Amenemhat I Sehetepibre (1985-1956 B. C.) ${ }^{13}$, Dynasty XII, probably the last decade of the king's reign.

\section{Measurements}

The block measures $133 \mathrm{~cm}$. in width at the widest point, the highest point is towards the block's right side is $84 \mathrm{~cm}$, and its thickness is between 29 and $33 \mathrm{~cm}$. These measurements are done by the restoration specialists of the Museum mentioned above. ${ }^{14}$ They are differ from those provided by the museum measurements database as $143 \mathrm{~cm}$. in width, and $69 \mathrm{~cm}$. in height with no record given for the thickness.

\section{Scene Description}

This is an upper lintel with a scene depicts the king twice inside a sed festival double shrine; once as king of Lower, and the other time as king of Upper Egypt. ${ }^{15}$ The king is shown to the right seated on a throne, wearing the crown of Lower Egypt, and holds a bundle of seven rnpt-signs with attached $S n$-sign in his left hand. The king receives the bundle from the right arm of the God Seth's emblem; who is holding an anx and a wAs scepter in his left hand. The king is shown again to the left, seated on a similar throne, wearing the crown of Upper Egypt and holding with his right hand another bundle of seven rnpt-signs he receives from an arm. At this point, the block is broken but it might be presumed that the arm is of the God Horus's emblem. The rnpt bundle has a small Sn-sign attached (Fig. 3).

The emblem of Seth has a combination of symbols hanging from the elbow of the arm holding the wAs and anx signs. This combination consists of the phonetic determinative , V 37 in Gardiner Sign List, which is used with the word $i d r,{ }^{16}$ "bind" ${ }^{17}$ or stitch (fig. 4$) .{ }^{18}$ This has hanging from it from the top going down one Hfn, the tadpole symbol of one hundred thousand, ${ }^{19}$ one Sn symbol of eternity, ${ }^{20}$ two xA , each is a symbol of one thousand, ${ }^{21}$ then two Sn, two more xA symbol and two more Sn.

In the scenes both halves; the king is wearing a long $s d$ robe and his thrones are low backed, cushioned and decorated on its sides with the smA tAwy representation. The $s d$ shrine is placed on a raised dais. At the side of the dais; there are some rxyt lapwing birds representing the people. ${ }^{22}$ Five complete ones and part of a sixth bird can be seen, with space for three more ones in the broken part to complete a set of nine rxyt.

The block's right part has two rnpt signs and a wAs scepter to their right, standing by the length of the scene. Between the two rnpt signs; there is a collection of symbols, starts from the top down with the symbol $\checkmark i d r$ that binds the two rnpt signs together in what may symbolize the binding of Upper and Lower Egypt. Below, is a figure of the God HH of infinity and the symbol of one million is seated between the two rnpt signs with his arms raised between them. Below HH is another combination of signs from the top going down: one Sn, one Hfn, another Sn, and two Dba; each is a sign of number ten thousand. ${ }^{23}$ Hanging from the two Dba; are two more Sn attached to two xA symbol, these are attached to two more Sn as well. The innermost rnpt sign has a tit amulet hanging from it. Although the block's left part is broken; it might be presumed the missing part will have similar arrangement of symbols. 
The scene has a $p t$ sky sign surmounting it and long flat sign similar to earth underneath the whole scene. The block still have traces of original colors. The $p t$ sign has traces of blue, the double-shrine has a yellow fill, the king's hands and the gods' emblem arms have traces of red color, the bundles of rnpt are black, and the throne is polychromatic with remnants of red, yellow, blue and black.

\section{The Inscriptions}

The right side of the scene; the king wears Lower Egypt's crown, and receives the bundle of rnpt from the Seth emblem. The text above the king in the right corner of the double shrine's right half, exactly above the arm of Seth emblem reads;

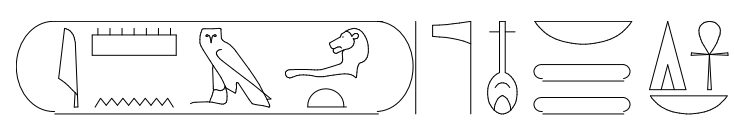

Imn-m-HAt nTr-nfr nb-tAwy di anx nb

Amenemhat (I) the Good God, Lord of the Two Lands, given all life.

Text below the arm of Seth emblem:

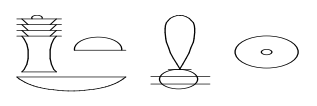

Ddt nb mi ra

All stability like Ra.

The left side of the scene is partly broken, however, the following text can be recognized;

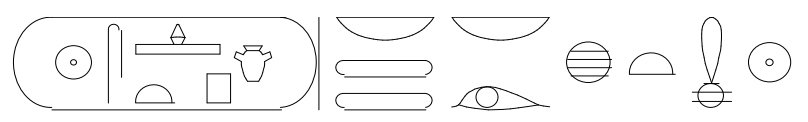

[s]Htp-ib-ra nb-tAwy nb-irt-xt mi-ra

Shetepibre, ${ }^{24}$ Lord of the Two Lands, Lord of things done, Like Ra.

Then a text in the broken part to the left of the block of which only part can be recognized;

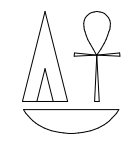

[di] anx nb

[Given] all life.

\section{Analysis of Data}

This scene drew the researcher's attention due to the unusual detail concerning the number of rnpt presented to the king. Each of the emblems of Horus and Seth is handing the king a bundle of seven rnpt signs (Figs. 1, 2, 3). Comparing similar scenes of other kings seated on double thrones inside the sed pavilion; the researcher found in most scenes the emblems of Horus and Seth handed the king one rnpt only. For example, a similar lintel dating back to the twelfth Dynasty during the reign of Senusert III, from Medamud, and now on display in the Egyptian Museum in Cairo J. d'E. 56497. This shows the emblems of Horus and Seth, each handing the king one rnpt sign (Fig. 5 a). ${ }^{25}$

Another lintel also from Medamud dating back to the thirteen Dynasty time of King Amenemhat-Sobekre II, Cairo J. d'E. 56496a, each god's emblem hands the king one rnpt (Fig.5 b) ${ }^{26}$ Two other scenes representing Amenhotep I in the double sed shrine from his temple at Qurna also receiving one rnpt from each of the emblems of the gods Horus and Seth; ${ }^{27}$ King Amenhotep III is shown on a similar scene from the temple of Luxor, also receiving one $r n p t$ from each god emblem (Fig. 6), ${ }^{28}$ as well as King Merenptah in a scene from Memphis (fig.7). ${ }^{29}$

Other scenes associating the rnpt with the sed-feast usually show one rnpt or two separate ones; such as the label of Hemaka from the time of Den in the first dynasty (Fig. 8), ${ }^{30}$ scenes of the sed-feast of Akhenatun (fig. 9), ${ }^{31}$ and those of Oserkon II (fig. 10). ${ }^{32}$ 
The researcher found few examples where more than one rnpt was handed to the king, or was associated with on e of the sed rites. The closest similarity to the scene studied here, comes from the same period, the Twelfth Dynasty, the time of Amenemhat III. A scene was carved on a block; once an upper lintel of a doorway in the king's temple at Tell B asta, erected for the celebration of the king's sed-festival. ${ }^{33}$ This shows the king inside the double sed pavilion with the $\mathrm{c}$ rowns of Upper and Lower Egypt, and receiving bundles of three rnpt from the emblems of the gods Seth and Horus res pectively (fig. 11).

The researcher also came across a scene from the tomb of Kheruef in which King Amenhotep III is shown celebr ating his first Sed. This scene presents a setting differ from that of the king receiving rnpt from the emblems of Horus a nd Seth. Instead, next to the king the goddess Hathor is seated and holding three rnpt in her hand (fig. 12). ${ }^{34}$

The seven rnpt represented on the block illuminated in this paper related to the meanings and symbolism associated with the number seven in Ancient Egypt. The number seven was frequently related to Osiris, ${ }^{35}$ whose association with the sed-feast is probable. ${ }^{36}$ This is probably hard to prove; as some Egyptologists find the association of Osiris with the sed-Feast is limited, ${ }^{37}$ and some even argue the sed-feast was a "renewal of the act of accession" in which the king represented Horus not Osiris. ${ }^{38}$ In some cases; the number seven have some sacred symbols such as the seven Hathors, the seven Maats, the seven uraei and other religious symbols, ${ }^{39}$ and its association with the scene on the block studied here might be revealed in forthcoming researchs.

Another detail that drew our attention is the emblem of Seth hands the rnpt bundle to the King of Lower Egypt, while the emblem of Horus -now missing- hands a similar bundle to the King of Upper Egypt in reverse to the usual association of Seth with the Upper Egypt's King, and that of Horus with the Lower Egypt's king. ${ }^{40}$ An attempt was made to draw the scene with the missing part showing how it must have looked with the God Horus emblem handing the rnpt bundle to the king wearing the crown of Upper Egypt (fig. 13). ${ }^{41}$ It might be hard to uncover the reason for this swap. Simpson suggests two probabilities; to been a mistake by the artist who was obliged to remove the block and could be the reason of reusing in foundations, or intended to emphasize the role Upper Egypt played to secure the king's sovereignty in the North. He adds, he finds neither probabilities convincing. ${ }^{42}$ It is probable, after a period of political unrest, before and at the beginning of the king's reign, there might have been political need to swap symbols of the Two Lands to emphasize the country unity. It might be noticed, the symbol $i d r$ expresses binding and gives indication of union was used more than once in the scene.

It is believed, the wAs signs on both right and left of the scene -and other similar scenes- were intended as a twoD representation of the world as the Egyptians imagined. ${ }^{43}$ They viewed it as a cube, with the sky above and earth underneath. This indicates the shrine in which the king is depicted on the studied block; was a representation of the world (Fig.14).

Arnold finds scenes from the Eleventh dynasty temple of King Montuhotep-Nebhepetre at Deir el-Bahari (Fig.15) was the inauguration of scenes where the king was represented in his funerary temple receiving the symbol of eternity from a god during his sed-feast. ${ }^{44}$ He supposes this to be an important change in the status of the king, who was reduced from the Old Kingdom when he was Lord of his pyramid complex and his cult was the center of the temple to a more human ruler in the Middle Kingdom depending on the gods to have immortality. ${ }^{45}$ The tradition that will continue in the following dynasties as seen in the examples mentioned above.

\section{Conclusion}

The block studied in this paper is an upper lintel, reused in the foundations of the mortuary temple walls to the east of the pyramid of Amenemhat I at Lisht. It is attributed to an earlier temple of the king dismantled in indeterminate date up till now. All option lead attribute these blocks to a building most probably of the later reign of Amenemhat I. The block was found with others, giving representations related to the sed-feast of King Amenemhat I. They were taken as an indication that Amenemhat I celebrated his first sed-feast in his late years, or died during the preparation for.

The block scene provides some points of interest. The king, who is shown twice inside the double throne pavilion, is receiving a bundle of seven rnpt instead of the usual one branch representing infinity. Another detail is the swapping of roles of the gods Seth and Horus, placing Seth as a symbol of Lower Egypt instead of his usual association with Upper Egypt, and the -now missing- figure of Horus as a symbol of Upper Egypt instead of Lower Egypt. Other pieces accompanying it are on display in both the Egyptian Museum in Cairo and the Metropolitan Museum of Art in New York awaiting further investigation of the structure, they once were part of. The scene is full with symbols emphasizing eternity and the union of the two lands as it is accustomed in scenes related to the sed-feast. 
Figures

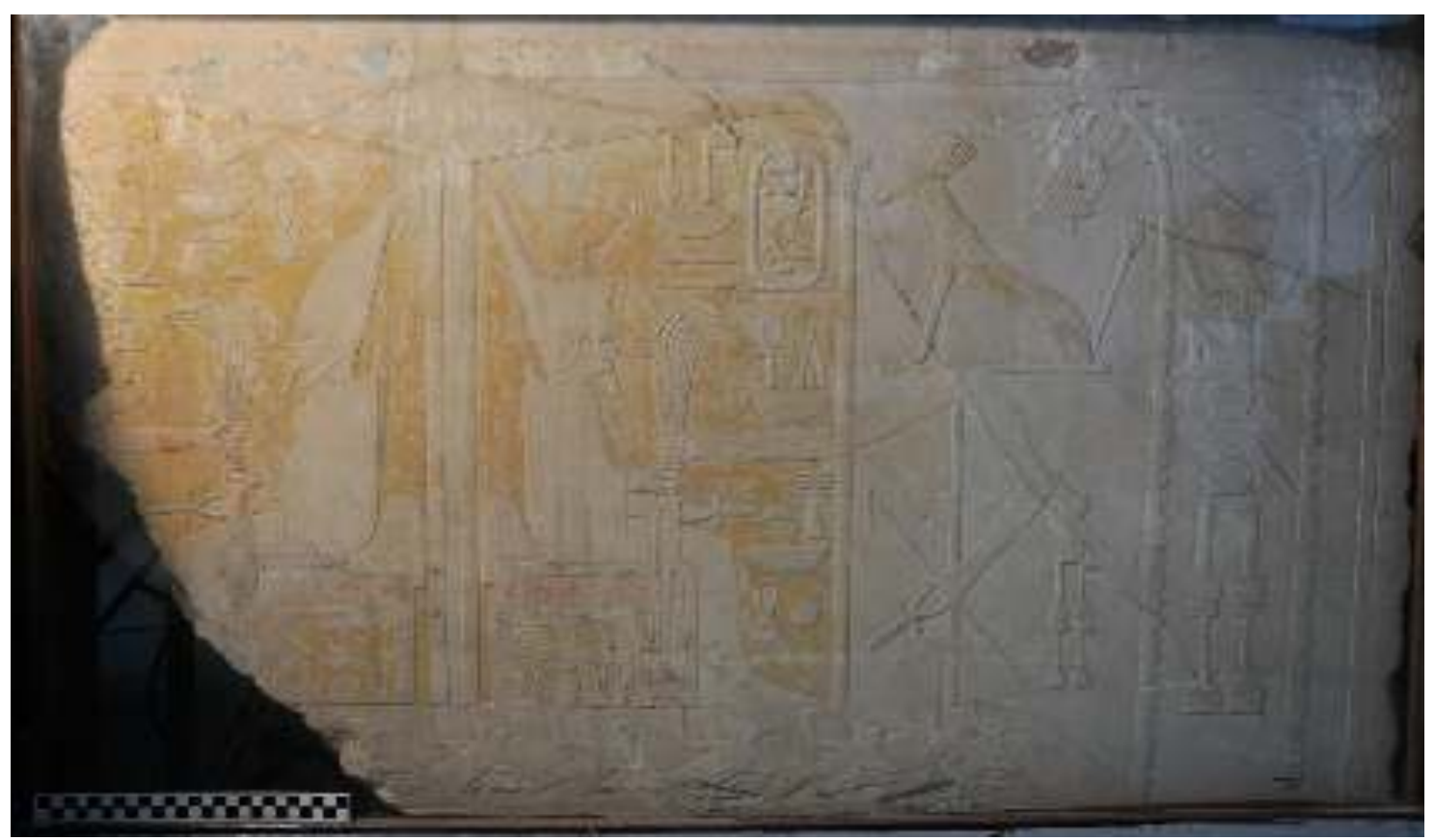

Fig. (1) Amenemhat I in the double sed-shrine. Egyptian Museum, Cairo. J. d'E. 40484.

Photo Taken by Mr. Sameh Abdel-Mohsen, the Egyptian Museum in Cairo photographer for our research. 


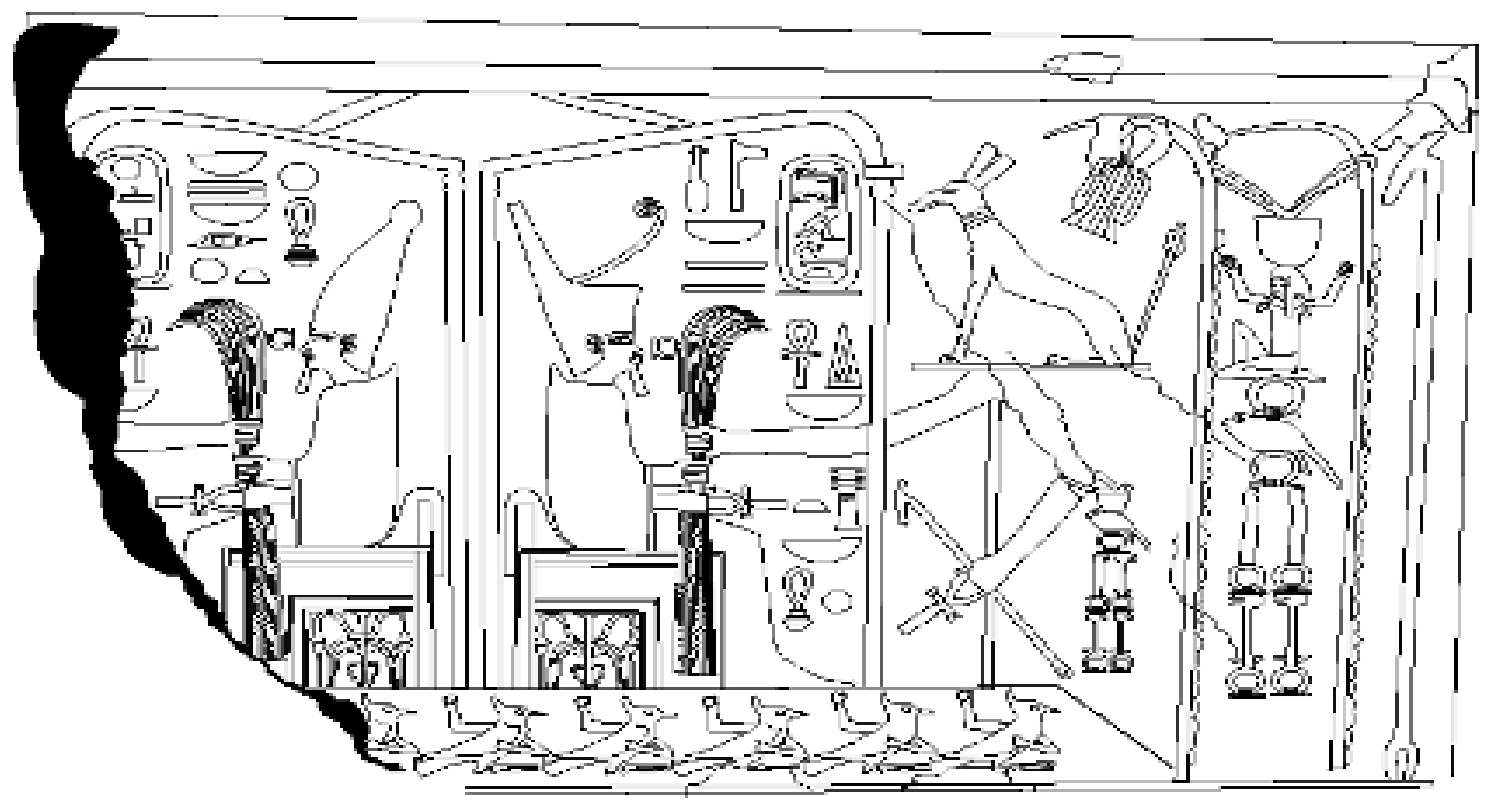

Fig. (2) Facsimilie of the scene on the block by Ms. Eman El-Saeed Ali.

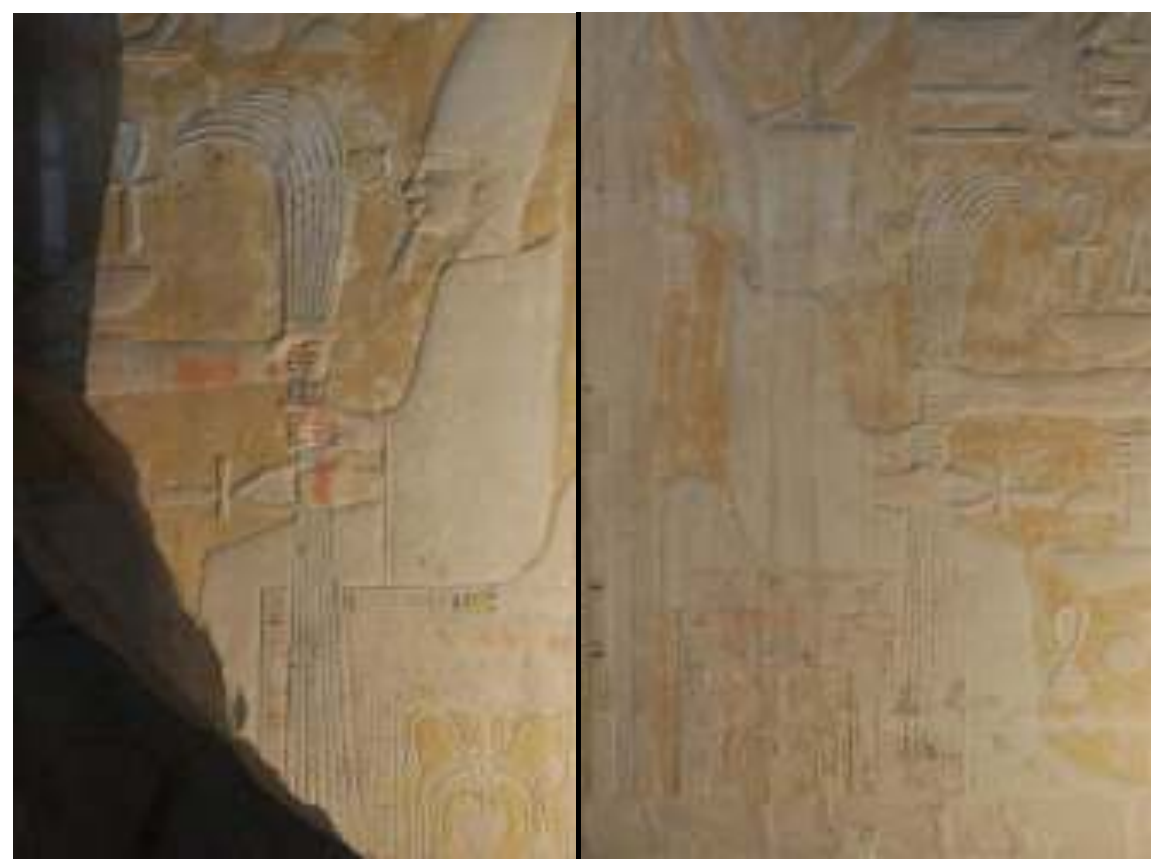

Fig. (3) Details of the block showing the king as he receives the bundle of seven rnpt as King of Upper Egypt and as King of Lower Egypt. 


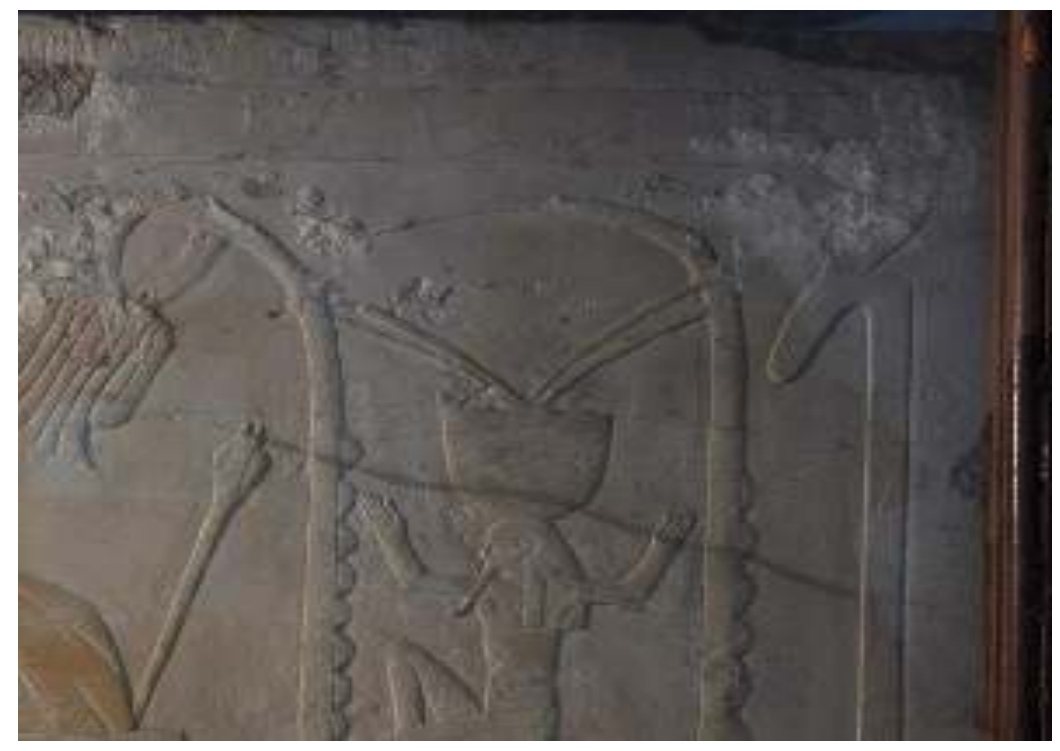

Fig. (4) The sign ${ }$ idr, "bind" joining the two rnpt signs together.

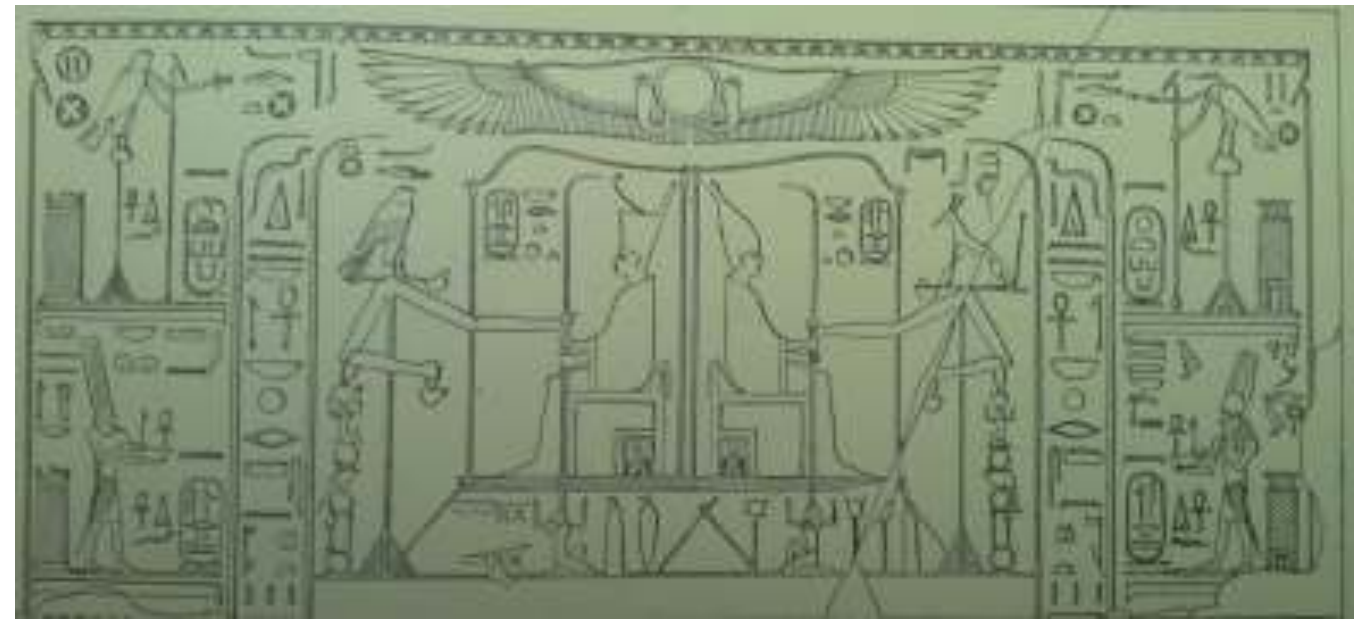

Fig. (5 a) A Lintel of Senusert III from Medamoud. Cairo J. d'E. 56497.

Cottevieille-Giraudet (1933), Pl. I, (detail).

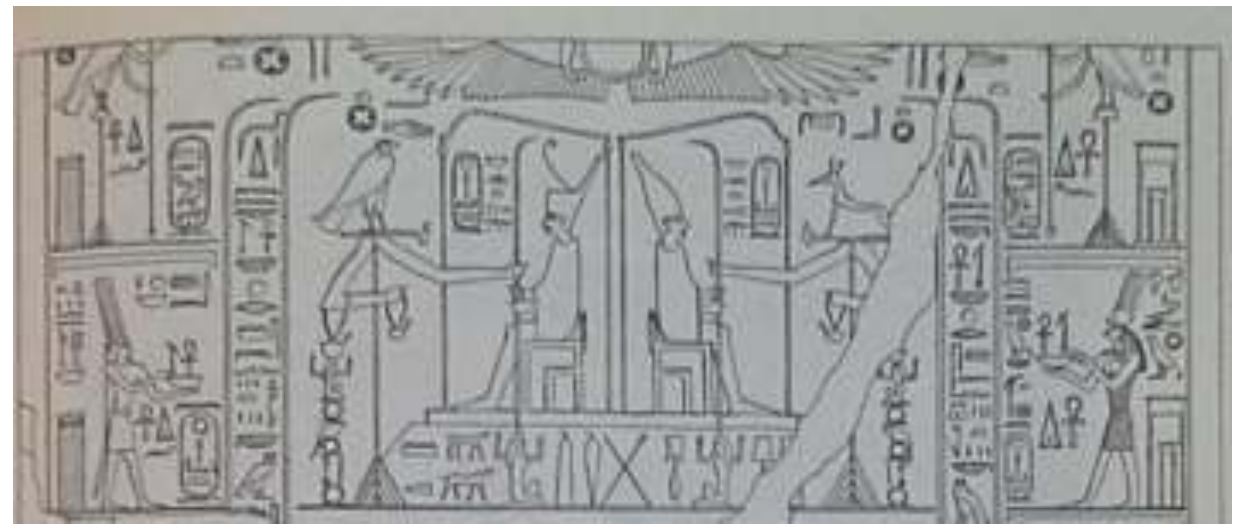

Fig. (5 b). A Lintel from the Thirteen Dynasty, time of King Amenemhat-Sobekre II. Cairo J. d'E. 56496a: Cottevieille-Giraudet (1933), PL. V, (detail). 


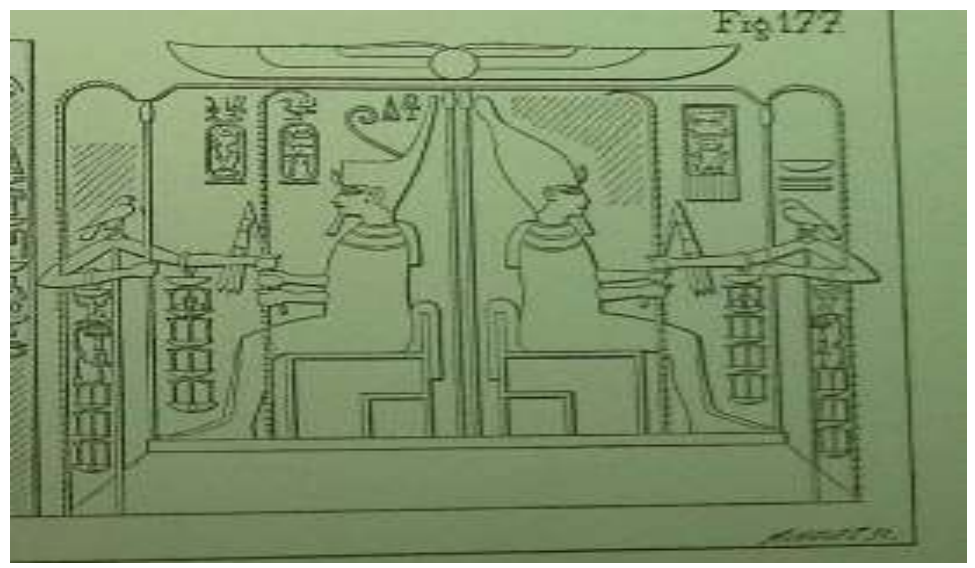

Fig. (6) Amenhptep III in the double sed-shrine.

A. Gayet (1894), Le Temple De Louxor, $1^{\text {er }}$ Fascicule, Constructions d'Aménophis III, Paris, PI. LXXI, (de tail).
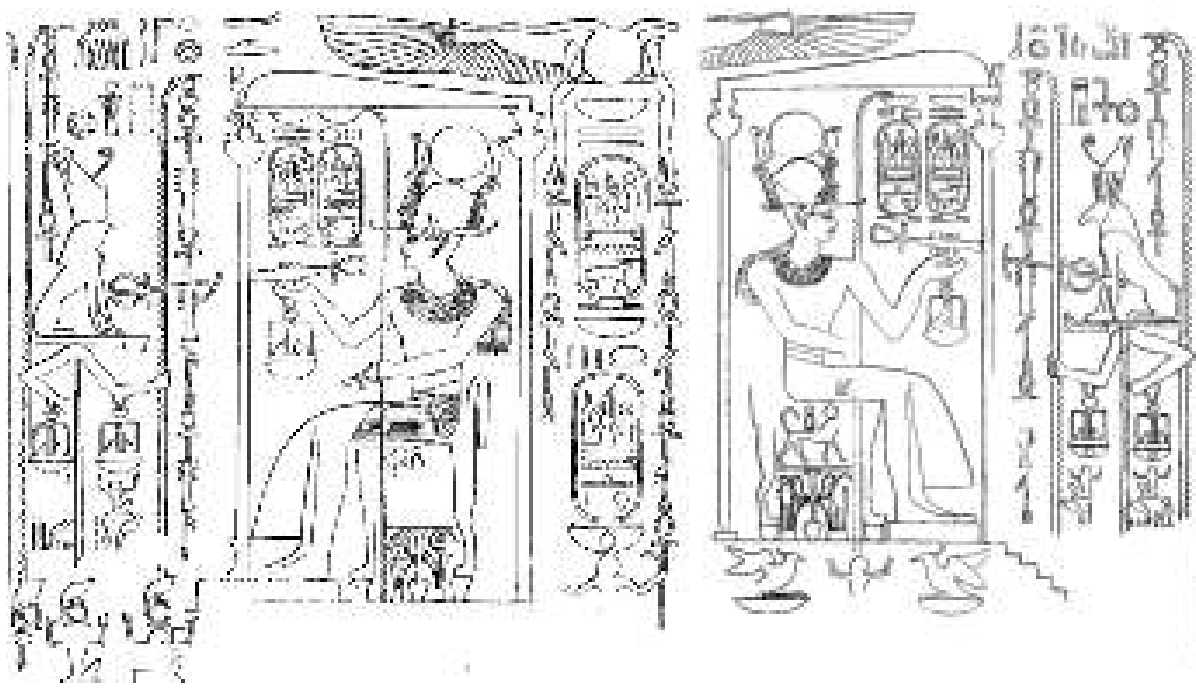

Fig. (7) A lintel from the time of Merenptah from his palace at Memphis.

W. F. Petrie (1909), The Palace of Apries: Memphis II, London, PI. XXI (detail).

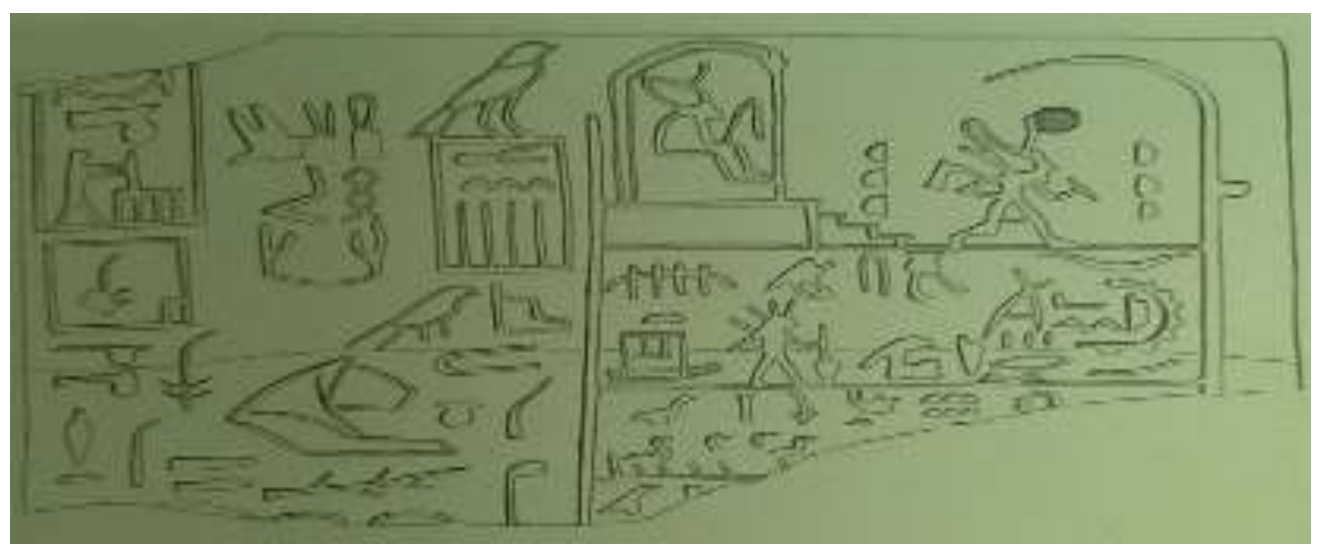

Fig. (8) The Hemka lable.

W. M. F. Petrie (1900), The Royal Tombs of the First Dynasty, London, PI. XV, 16. 


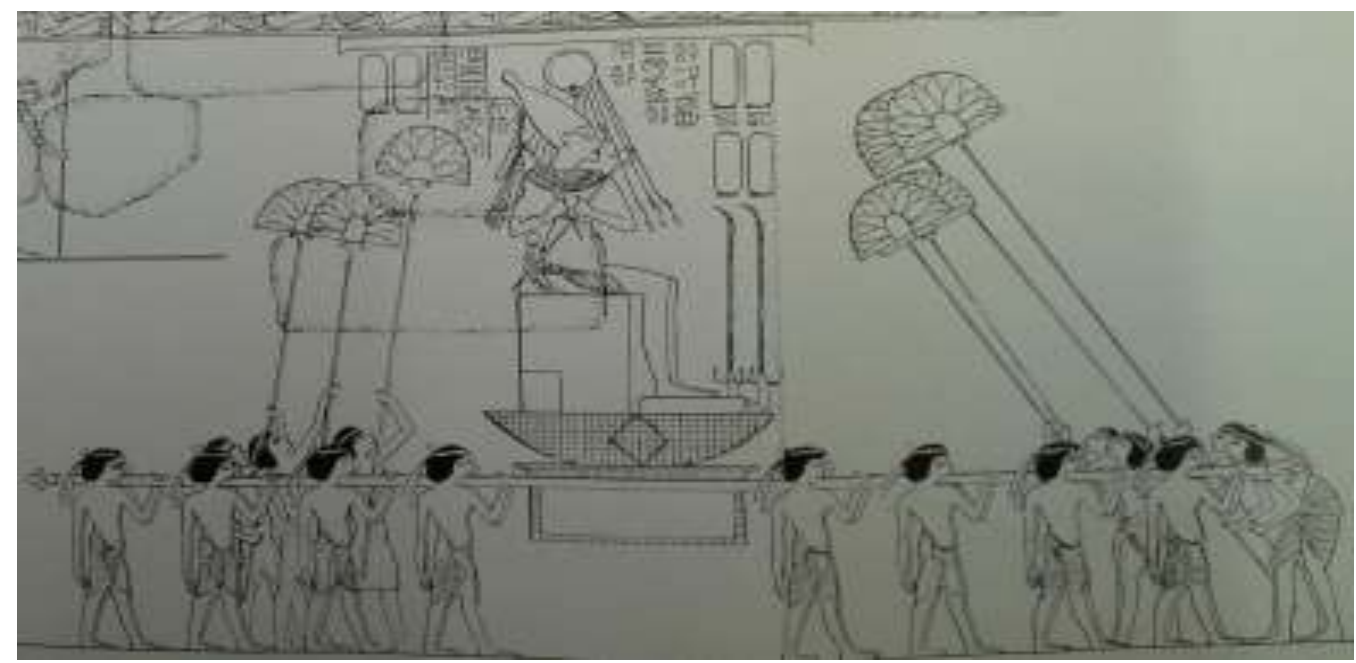

Fig. (9) A scene of the sed-feast of Akhenatun at Karnak. J. Gohary (1992), Akhenatun Sed Festival at Karnak, London, pl. I, (detail).

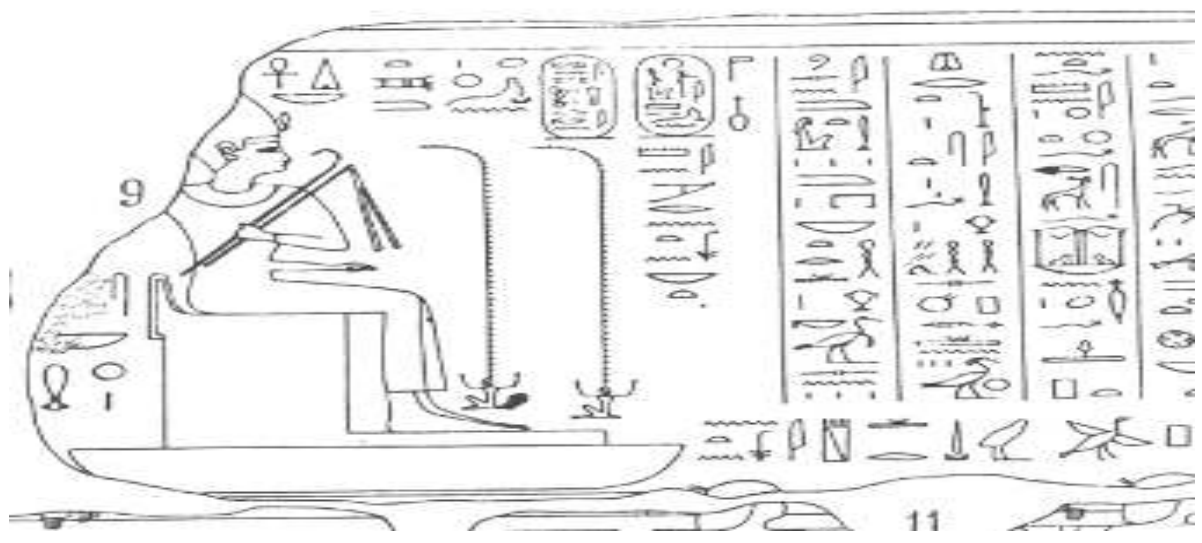

Fig. (10) Scene from the Sed-feast of Oserkon II.

E. Naville (1892), The Festival-Hall of Osorkon II in the Great Temple of Bubastis, Tenth Memoire of the $E E F$, London, pl. III (detail).

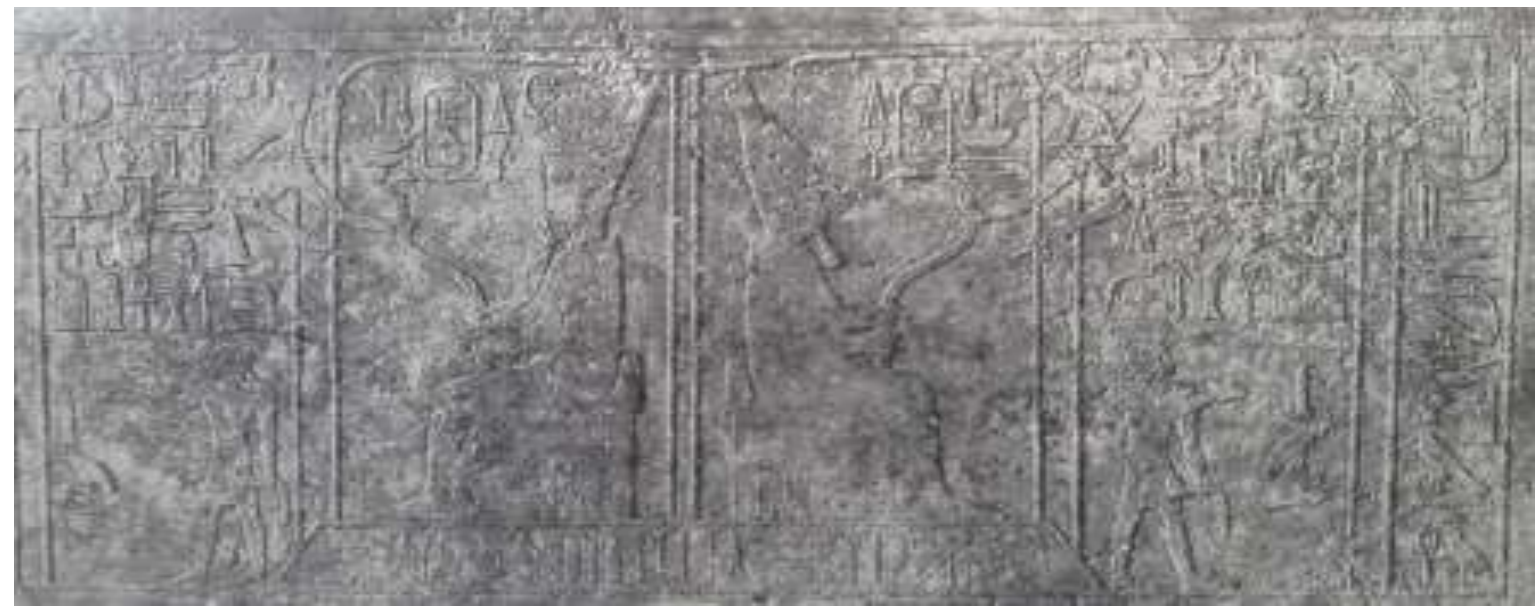

Fig. (11) Amenemhat III receiving three rnpt from the emblems of Horus and Seth. Farid (1964), pl. X. 


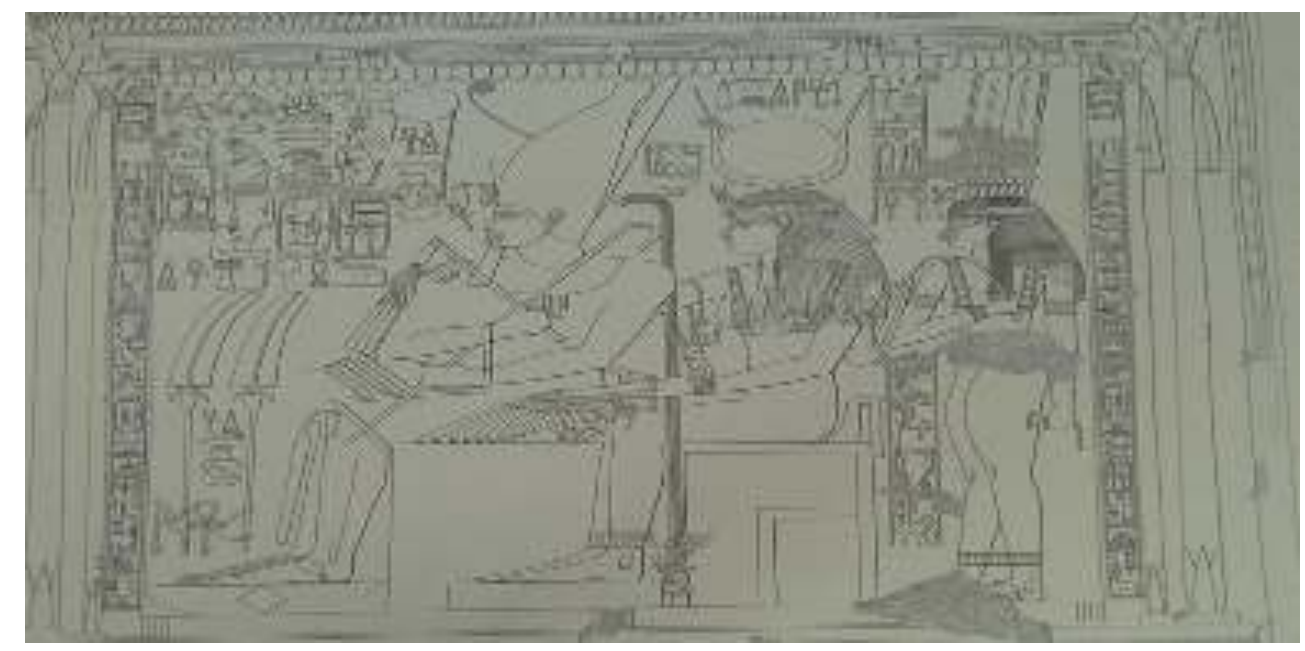

Fig. (12) A scene of the first sed-feast of Amenhotep III with goddess Hathor holding three rnpt sign. The Epigraphic Survey. (1980), The Tomb of Kheruef: Theban Tomb 192. The Oriental Institute Publications 102. Chicago, Pl. 26.

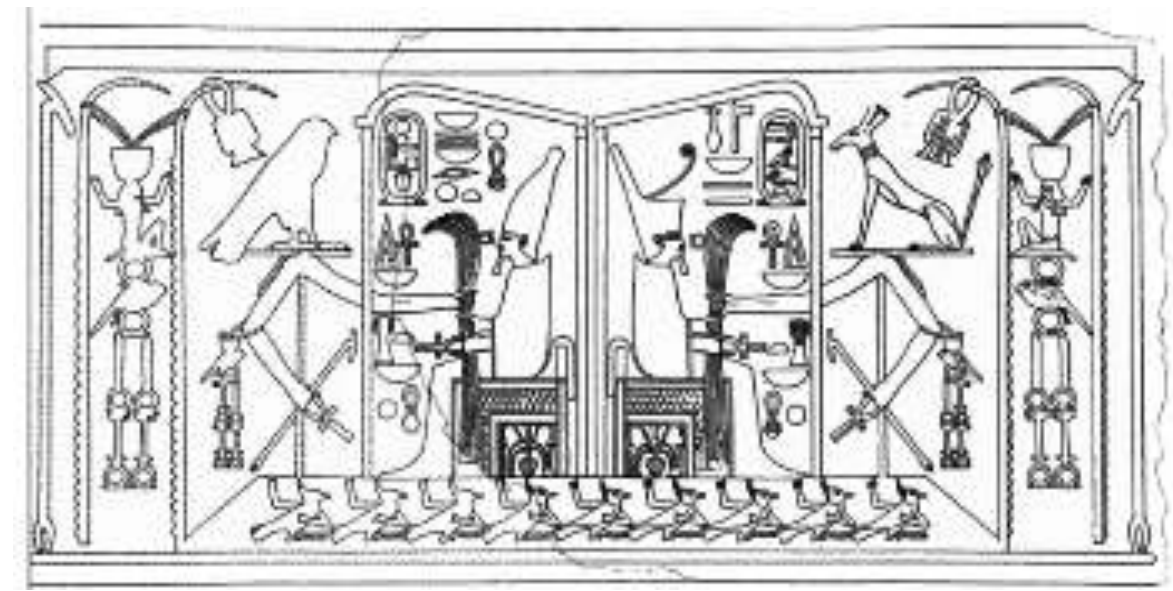

Fig. (13) Drawing of the block with the missing part as imagined by Barry Girsh. Shafer, Arnold \& others (1997), figure 33.

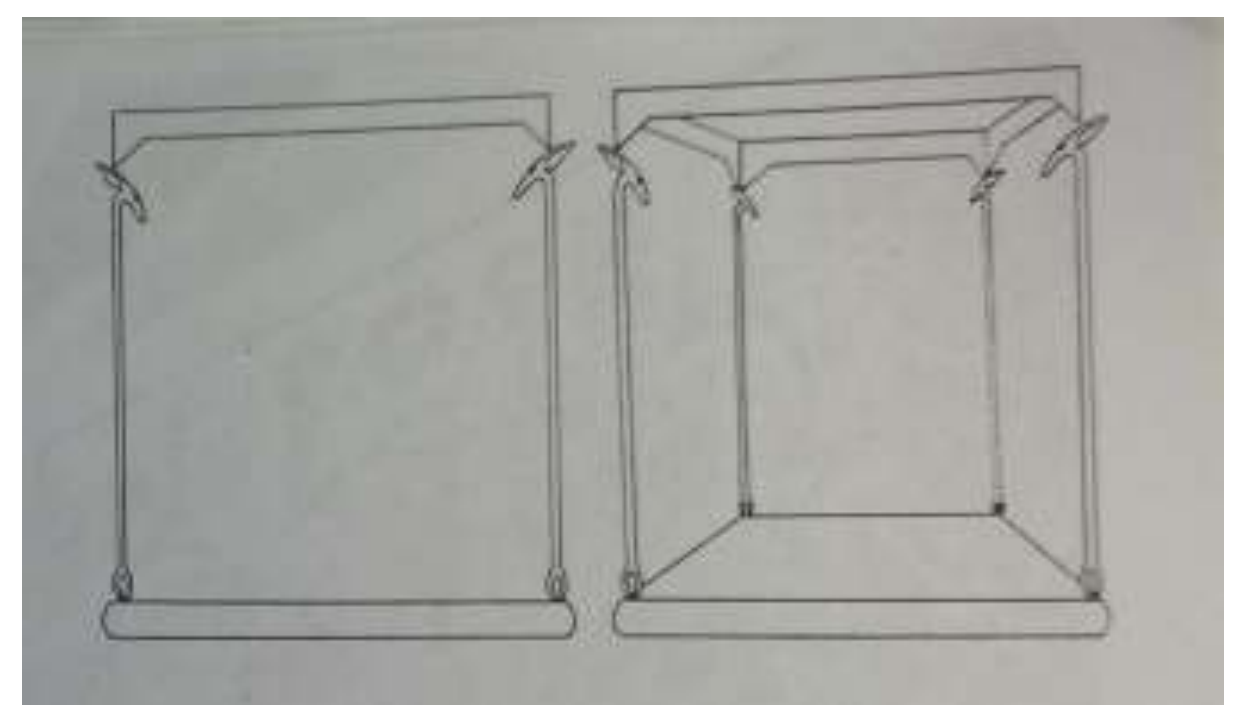

Fig. (14) A 2-D representation of the Ancient Egyptians view of the world.

R. H. Wilkinson (1994), Symbol and Magic in Ancient Egyptian Art, London, fig. 86-87. 


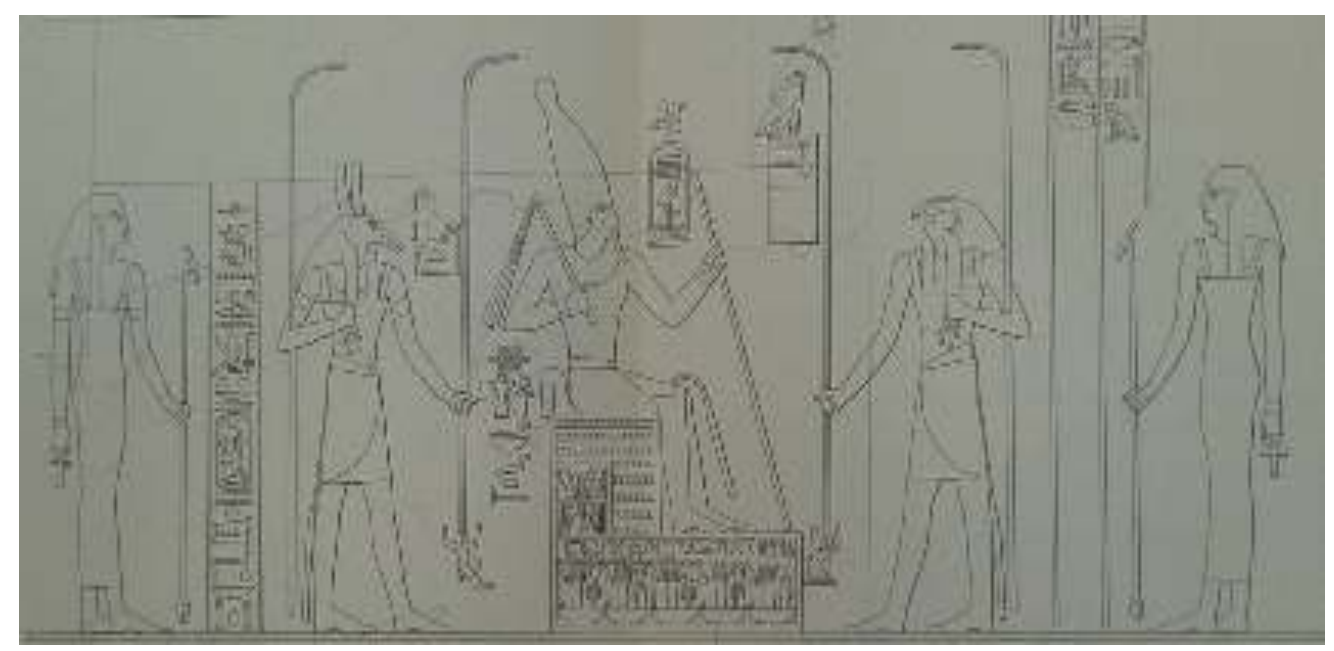

Fig. (15) Montuhotep-Nebhepetre receiving rnpt signs from the gods Horus and Seth. Arnold (1974), pl. 10.

\section{Endnotes}

${ }^{1}$ J. E. Guatier and G. Jequier (1902), Fouilles de Lisht, MIFAO VI; J. E. Guatier and G. Jequier (1896), El-Lisht Pyramid-Field, Revue Archéologique $3^{\circ}$ Sér. xxix, 36-70.

${ }^{2}$ See the journals of the Egyptian Expedition Excavations: A. Lythgoe (April 1907), BMMA II; p. 61-63; A. C. Mace (October 1908), BMMA III, 184-8; A. C. Mace (October 1914), BMMA IX, p. 207-220; A. C. Mace (November 1921), BMMA XVII, 5-19 and A. C. Mace (December 1922), BMMA XVII, 4-18.

${ }^{3}$ Other reused blocks from the earlier building of Amenemhat I were mentioned in: B. Porter and R. L.B. Moss (1934), Topographical Bibliography of Ancient Egyptian Hieroglyphic Texts, Reliefs and Paintings, Vol. IV, Lower and Middle Egypt, Oxford, p. 77 with no mention of this block.

${ }^{4}$ W. K. Simpson (1963), Studies in the Twelfth Egyptian Dynasty, II, The Sed Festival in Regnal Year 30 of Amenemh at III and the Periodicity of the Festival in Dynasty XII, JARCE 2, p. 60.

${ }^{5}$ W. C. Hayes (1953), The Scepter of Egypt, A Background for the Study of the Egyptian Antiquities in the Metropolitan Museum of Art, I, New York, p. 172, figure 103.

${ }^{6}$ D. Arnold (1992), Amenemhat I and the Early Twelfth Dynasty at Thebes, Metropolitan Museum of Art Journal, 26, 15, Digital pdf copy via www.JSTOR.org.

${ }^{7}$ Simpson (1963), p. 60; Hayes, (1953), pp. 172-3 and figure 104.

${ }^{8}$ Simpson (1963), p. 60.

${ }^{9}$ Hayes (1953), p. 172-3 and figure 104.

${ }^{10}$ Arnold (1992), p. 15.

${ }^{11}$ Arnold (1992), p. 16. This however is a matter of debate awaiting further research, see: I. Shaw (2000), The Oxford History of Ancient Egypt. Oxford, p. 159.

${ }^{12}$ The main evidence for this opinion is a statue in the Egyptian Museum of Cairo J. d'E. 60520 that bears a text mentioning the celebration of the first sed of the king: Simpson (1963), p. 60.

${ }^{13}$ According to the Oxford dating: Shaw (2000), The Oxford History of Ancient Egypt, p. 158. Other Egyptologist use a different dating though and puts the king's reign between 1991-1962 BC: J. v. Beckerath (1975), Amenemhet I, LÄ I , pp. 188; Arnold (1992), p. 39.

${ }_{15}^{14}$ A percentage of error might be expected because the measurements were taken without removing the glass frame.

15 Simpson (1963), p. 61.

${ }^{16}$ A. Gardiner (1979), Egyptian Grammar, Third Edition. Oxford, p. 527, V 37.

${ }^{17}$ For the use of this sign in scenes related to sed-feast: E. Hornung and E. Stachelin (2006), Neue Studien zum Sedfeste, Basel, p. 57.

18 A. Gardiner (1947), Ancient Egyptian Onomastica, vol. II, Oxford, p. 260; A. Erman and H. Grapow (1971), Wörterbuch Der Aegyptichen Sprach, vol. I, Berlin, p. 154, 17-18.

${ }^{19}$ Gardiner (1979), p. 475, I 8.

${ }^{20}$ Gardiner (1979), p. 522, V 9.

${ }^{21}$ Gardiner (1979), p. 480, sign M 12.

${ }^{22}$ Gardiner (1979), p. 470, G 23.

${ }^{23}$ For symbolism of these signs: R. H. Wilkinson (1992), Reading Egyptian Art, London, p. 39; 107; $119 ; 193$.

${ }^{24}$ For the titles of the king see: J. v. Beckerath (1975), Amenemhet I, LÄ I, 188; Arnold (1992), p. 18.

${ }^{25}$ R. Cottevieille-Giraudet (1933), Les Fouilles de Médamoud (1931) les monuments du Moyen Empire, FIFAO 9, Cari 
o, Pl. I.

${ }^{26}$ Cottevieille-Giraudet (1933), Pl. V; B. Shafer, D. Arnold, \& others (1997), Temples of Ancient Egypt, New York, figu re 36.

${ }^{27}$ H. E. Winlock (1917), A Restoration of the Reliefs from the Mortuary Temple of Amenhotep I, JEA IV, London, pl. I II \& IV.

${ }^{28}$ A. Gayet (1894), Le Temple De Louxor, $I^{\text {er }}$ Fascicule, Constructions d'Aménophis III, Paris, Pl. LXXI, detail.

${ }^{29}$ W. F. Petrie (1909), The Palace of Apries: Memphis II, London, Pl. XXI.

${ }^{30}$ W. M. F. Petrie (1900), The Royal Tombs of the First Dynasty, London, Pl. XV, 16.

${ }^{31}$ J. Gohary (1992), Akhenatun Sed Festival at Karnak, London, Pl. I.

${ }^{32}$ E. Naville (1892), The Festival-Hall of Osorkon II in the Great Temple of Bubastis, Tenth Memoire of the EEF, London, pl. III.

${ }^{33}$ S. Farid (1964), Preliminary Report on the Excavations of the Antiquities Department at Tell Basta (season 1961), ASAE LVIII, Cairo, 90; 95.

${ }^{34}$ The Epigraphic Survey (1980), The Tomb of Kheruef: Theban Tomb 192. The Oriental Institute Publications 102. Chicago, Pl. 26.

${ }^{35}$ R. H. Wilkinson (1994), Symbol \& Magic in Egyptian Art, London, p. 136.

${ }^{36}$ For more details about the sed feast and its associations with different deities see: E. Uphill (1965), The Egyptian Sed-festival rites, JNES 24, (4), 365-383 and C. J. Bleeker (1967), Egyptian Festivals, Enactment of Religious Renew, Studies in the History of Religion XIII, Leiden, the chapter entitled Hb-Sd, p. 97-123.

${ }^{37}$ J. G. Griffith (1955), The Costume and Insignia of the King in the Sed-Festival, JEA 41, 127-128.

${ }^{38}$ A. Gardiner (1915), The Golden Bough: Adonis, Attis, Osiris; Studies in the History of Oriental Religion by J. G. Frazer, Review, JEA 2, 124.

${ }^{39}$ H. Goedicke (1986), Symbolische Zahlen, LÄ VI, p. 128.

${ }^{40}$ Hayes (1953), 26-27.

${ }^{41}$ Shafer, Arnold, \& others (1997), figure 33.

${ }^{42}$ Simpson (1963), p. 60, FN. 39.

${ }^{43}$ R. H. Wilkinson (1994), Symbol and Magic in Ancient Egyptian Art, London, fig. 86-87.

${ }^{44}$ D. Arnold (1974), Der Tempel des Königs Mentuhotep von Deir el Bahari,vol. II, Die Wandreliefs des Sanktuares, $A V$ 11, pl. 10. This scene is on the walls of a sanctuary that was added for the king's sed feast in the center of the hypostyle hall of the temple.

${ }^{45}$ Shafer, Arnold, \& others (1997), p. 75-76.

\section{عتب خاص بأمنمحات الأول بالمتحف المصري بالقاهرة}

موضوع هذا البحث هو كتلة من الحجر الجيري وجدت بمنطقة اللثت في المجموعة الجنائزية الخاصة بالملك أمنمحات الأول، ومحفوظة حاليا

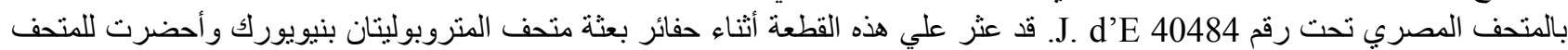

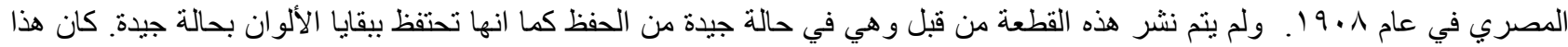

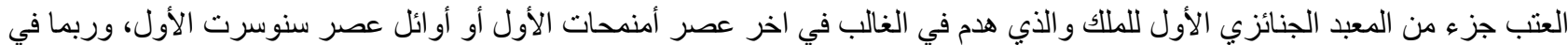

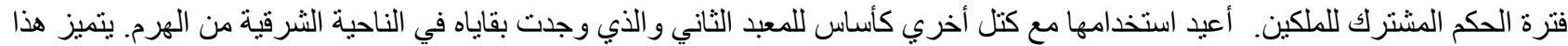

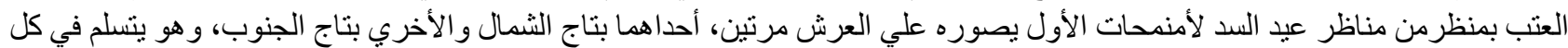

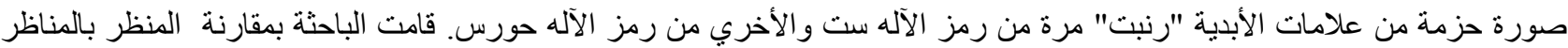

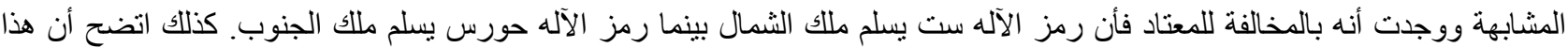

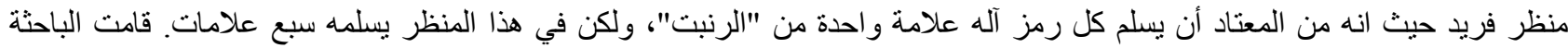

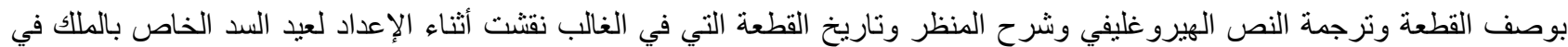

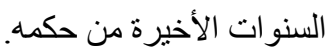

